\title{
Hyperglycemia associated with Chagas disease
}

\author{
Asociación de hiperglucemia y la enfermedad de Chagas \\ Imelda Menchaca Armenta ${ }^{a}$, Antonio E. Gutiérrez Rodríguez ${ }^{b}$, Hortencia Cortes Pérez ${ }^{c}$, \\ Jessica Zaragoza Cortes ${ }^{d}$ y Karen Zamora Cerritos ${ }^{e}$
}

\begin{abstract}
:
Chagas disease and type 2 diabetes mellitus are the two main causes of Years Lived with Disability. The consequences and possible interaction between both illnesses have been scarcely studied. A population study of blood donors from the Centro Estatal de Transfusión Sanguinea (CETS) was carried out with a reagent related to the Chagas test. Detection was carried out with an enzyme-linked immunosorbent assay (ELISA) of anti- Trypanosoma cruzi antibodies and also, an HbA1C test was performed with $4 \mathrm{~mL}$ of whole blood. Descriptive statistics were used to analyze quantitative and qualitative data. The Chisquare test was applied to determine the existence of an association between hyperglycemia and Chagas disease. A total of 4,952 participants were screened. All of the participants (100\%) were from Hidalgo State and did not have a chagoma as evidence of having been bitten or denied contact with a "kissing bug". Of the total, 26 reacted to the first screening test to detect anti-Trypanosoma cruzi antibodies; of these, five were confirmed as positive on the second screening test. The seroprevalence of $T$. cruzi was $0.01 \%$. The results do not show a clear association but the frequency of hyperglycemia in population with Chagas coincides with that reported by other authors. Considering the scarce clinical-epidemiological evidence between Chagas disease, obesity, and hyperglycemia, long-term follow up of both morbidities is an area of opportunity for clinical and epidemiological study of $T$. cruzi reactivity.
\end{abstract}

Keywords:

Diabetes mellitus, Trypanosoma cruzi, detection, obesity

\section{Resumen:}

La enfermedad de Chagas junto a Diabetes mellitus tipo II constituyen dos de las principales causas de años de vividos con discapacidad. Las consecuencias y posibles interacciones entre ambos padecimientos se encuentran poco estudiados. Se realizó un estudio con población de donadores de sangre del Centro Estatal de la Transfusión Sanguínea (CETS), con resultado reactivo a la prueba de Chagas. La detección se realizó por el método de ensayo inmunoenzimático (ELISA) para anticuerpos anti-Trypanosoma cruzi y se realizó la prueba de A1c en $4 \mathrm{ml}$ de sangre total. Se realizó estadística descriptiva de las variables cuantitativas y cualitativas. Se aplicó la prueba de ji-cuadrada para la determinación de la existencia de asociación entre hiperglicemia y la enfermedad de Chagas. 4952 participantes fueron tamizados. El 100\% indicaron ser originario de los Hidalgo y no haber presentado chagoma de inoculación, así como conocer o haber convivido con chinches besuconas. Del total, 26 fueron reactivos a la primera prueba de tamizaje para detección de anticuerpos anti-Tripanosoma cruzi, de los cuales cinco confirmados como reactivos para la segunda prueba de tamizaje. Se obtuvo una seroprevalencia de T. cruzi de $0.01 \%$. Los resultados de la asociación no muestran una asociación clara pero la frecuencia de hiperglucemia en

\footnotetext{
a Corresponding author, Servicios de Salud de Hidalgo, Coordinación de Investigación en Salud, Hidalgo, México, https://orcid.org/00000003-3323-8587, Email: imeldamenchacaa@gmail.com.

b Centro Estatal de Transfusión Sanguínea, Hidalgo, México, https://orcid.org/0000-0002-4768-0176, Email: aegr_dr78@hotmail.com. c Centro Estatal de Transfusión Sanguínea, Hidalgo, México, https://orcid.org/0000-0002-0589-2517, Email: cortesperezh@ gmail.com. d Servicios de Salud de Hidalgo, Coordinación de Investigación en Salud, Hidalgo, México, https://orcid.org/0000-0002-0289-6037, Email: jskzara@hotmail.com.

e Servicios de Salud de Hidalgo, Coordinación de Investigación en Salud, Hidalgo, México, https://orcid.org/0000-0002-1997-1080, Email: karenzamoracerritos@gmail.com.
} 
población chagasica coincide con lo reportado con otros autores. Considerando la escasa evidencia clínica-epidemiológica entre la enfermedad de Chagas, la obesidad e hiperglucemia, el seguimiento a largo plazo de ambas comorbilidades constituye un área de oportunidad para el estudio clínico y epidemiológico de los reactivos a T. cruzi.

\section{Palabras Clave:}

Diabetes mellitus, Trypanosoma cruzi, detección, obesidad

\section{INTRODUCTION}

Chagas disease (CD) or American trypanosomiasis is caused by the protozoa Trypanosoma cruzi (Chagas, 2009). It is estimated that worldwide there are between 6 and 7 million people infected by $T$. cruzi. The disease, previously considered endemic in Latin America, has been seen more frequently in recent decades in the United States of America and Canada, as well as in European countries, and the West Pacific (World Health Organization, 2021). It is characterized by an acute and chronic phase. It is estimated that approximately $70 \%$ of those infected are asymptomatic all their lives and only some cases evolve to symptomatic chronic stages associated with heart, digestive system, and/or nervous system lesions. The acute phase occurs immediately after infection and can last weeks or months; during this phase, a large number of parasites circulate in the blood (Saumell \& Soriano-arandes, 2015). In less than $50 \%$ of those infected, the disease presents as a skin lesion or a purplish swelling of one of the eyelids; occasionally fever, headache, enlarged lymph nodes, paleness, muscle pain, shortness of breath, swelling and abdominal or chest pain can occur. In $60 \%$ of chronic phase cases, the parasites remain hidden in heart and digestive muscle as well as in adipocytes, with the latter representing an important reservoir of parasites (Combs et al., 2005).

In Mexico, the current prevalence is controversial (Dumonteil, 1999). It is believed that cases of CD are unreported and that the true number of individuals infected by different routes is unknown (Carabarin-Lima et al., 2013). In the 80s, the Encuesta Nacional de Seroepidemiología (ENSE) recorded a prevalence of $T$. cruzi seropositive individuals in the country of $0.1 \%$ and $5 \%$. As part of the results, a prevalence of $3.2 \%$ was found in the state of Hidalgo (Velasco- Castrejon et al., 1992). The state is considered one of the eight states that concentrate 69\% of seropositive cases (Ramsey et al., 2003).

$\mathrm{CD}$ is one of the ten main causes of Years Lived with Disability (Lozano et al., 2014). Type 2 diabetes mellitus has become a serious health problem in Mexico, because of its high prevalence and its high degree of mortality. With regard to the burden of disease, up to 2010, type 2 diabetes mellitus was the second cause of death in Mexico and one of the main causes of Years Lived with Disability (Barraza Lloréns et al., 2015).

Recently, the relationship between adipocytes and infectious agents has been studied since it has been shown that adipose tissue plays an important role in the inflammatory response of the infection (Neyrolles et al., 2006); In agents such as Mycobacterium tuberculosis and Rickettsia prowazekii, it has been reported that adipose tissue is an important reservoir where M. tuberculosis persists in a state of dormancy as a defense mechanism, thus avoiding antimycobacterial drugs (Bechah, Paddock, Capo, Mege, \& Raoult, 2010) (Nagajyothi et al., 2009). In $T$ cruzi infection, fat and glucose metabolism are related, creating an inflammatory phenotype that affects a variety of inflammatory processes as a result of adipocyte and fat tissue infection (dos Santos et al., 1999).

Although the clinical and epidemiological evidence linking Chagas disease, obesity, and diabetes is scarcely studied, there has been recent interest in the association between $T$. cruzi infection and adipose tissue for several reasons (Hidron et al., 2010) (Nagajyothi et al., 2012). In these studies, it has been shown that the presence of $T$. cruzi in adipocytes and fat tissue shows alterations in different metabolic pathways during the first stages of the infection, and these persist until the chronic phase. In this sense, $T$. cruzi shows a high affinity for lipoproteins, which facilitate the invasion of cells by the parasite favoring its permanence in adipocytes and fat tissue (Desruisseaux, Nagajyothi, Trujillo, Tanowitz, \& Scherer, 2007). It has been established that adipocytes and fat tissue are objects of infection and a storage site from which subsequent infection can originate, particularly in circumstances of immunosuppression (Secretaria de Salud, 2012). Few studies have addressed the association of $T$. cruzi infection and its affinity for adipocytes. En 1999, dos Santos y colaboradores reportaron mayor frecuencia de hiperglucemia y DM2 en mujeres que padecían enfermedad de Chagas en su forma cardíaca crónica en comparación con otras presentación de la enfermedad(dos Santos et al., 1999).

CD and DM2 are diseases that are present in the population of Hidalgo; however, the possible interactions between both illnesses, the number of people affected in our setting and their possible long-term complications have been little studied. Therefore, the objective of this work was to determine the possible association between hyperglycemia and Chagas disease.

\section{MATERIAL AND METHODS}

An analytical cross-sectional study was carried out. The population's study was blood donors from the Centro Estatal de la Transfusión Sanguinea (CETS) with a positive Chagas test. The study participants were blood donor candidates that met the requirements of NORMA Oficial Mexicana NOM253-SSA1-2012 for the use of human blood and blood products with therapeutic purposes (Secretaria de Salud, 2012), with a positive Chagas test, and who provided signed informed consent. In Mexico, the detection of T. cruzi 
antibodies is mandatory for all blood components used for transfusion. Detection was carried out using screening and supplementary testing by enzyme-linked immunosorbent assay (ELISA) for anti-Trypanosoma cruzi antibodies. After a positive reaction was obtained with the screening test, $\mathrm{HbA1c}$ was measured in $4 \mathrm{~mL}$ of previously collected and separated whole blood. La cuantificación de HbA1C en sangre total se realizó a traves del método de colorimetria. Los niveles de HBA1C fueron categorizados de acuerdo a los criterios establecidos por la American Diabetes Association (ADA),se definió como hiperglucemia igual y mayores a $5.7 \%$ (American Diabetes Association, 2021).

Data were captured in Microsoft Excel ${ }^{\circledR}$ and were analyzed with the statistical program SPSS $®$. Descriptive statistics were used to analyze quantitative and qualitative data. The chisquared test was applied to determine the existence or not of an association between the dependent variable, hyperglycemia, and the independent variables, such as Chagas disease.

\section{RESULTS}

A total of 4,952 individuals participated, of which 26 were positive for anti-Trypanosoma cruzi antibodies on the first screening test. Of these 26 samples, five were positive on the second anti-Trypanosoma cruzi antibody screening test.

The five individuals with confirmed positive samples were men with a mean age of $35.8 \pm 13$ years. Forty percent did not have an education and $80 \%$ were employed at the time of the study. Also, $100 \%$ stated that they had been born in one of the municipalities of the State of Hidalgo and that they had never had a chagoma or contact with Triatomas or "kissing bugs". The estimated seroprevalence of $T$. cruzi in the donor candidate population of the SBTC was $0.1 \%$

Regarding body mass index (BMI), two participants were classified with normal weight, one with overweight, and two with obesity. According to the classification of $\mathrm{HbA1c}$ values established by the American Diabetes Association (VelascoCastrejon et al., 1992), $100 \%$ of the participants had diabetes (Table 1).

Table 1. Frequency of BMI and HbA1c in donors positive for Chagas.

\begin{tabular}{lll}
\hline Characteristic (N= 5) & $\begin{array}{l}\text { Frequen } \\
\text { cy }\end{array}$ & $\mathbf{\%}$ \\
\hline BMI & & \\
$\quad$ Low Weight $(<19)$ & 0 & 0 \\
$\quad$ Normal $(20-24.9)$ & 2 & 40 \\
$\quad$ Overweight $(25-29.9)$ & 1 & 20 \\
$\quad$ Obesity $(>30)$ & 2 & 40 \\
HbA1c & & \\
$\quad$ Normal (less than 5.7\%) & 0 & 0 \\
$\quad$ Prediabetes (5.7 - 6.4\%) & 0 & 0 \\
$\quad$ Diabetes $(6.5 \%$ or more) & 5 & 100 \\
\hline
\end{tabular}

BMI, body mass index; HbA1c, glycated hemoglobin.
The results of the association of hyperglycemia and Chagas disease showed a P value of 0.053 (Table 2). However, it is noteworthy that $100 \%$ of the positive cases of CD had $\mathrm{HbA1c}$ values equal to or greater than $6.5 \%$.

Table 2. Association of anti-Trypanosoma cruzi antibodies and blood glucose values.

\begin{tabular}{|c|c|c|c|c|c|c|}
\hline \multirow{5}{*}{ HbA1c } & \multicolumn{4}{|c|}{ ELISA } & \multirow[b]{5}{*}{$\boldsymbol{P}$} & \multirow{5}{*}{$\begin{array}{l}\text { Tot } \\
\text { al }\end{array}$} \\
\hline & \multicolumn{4}{|c|}{ Positiv } & & \\
\hline & $\mathbf{e}$ & & Neg & ive & & \\
\hline & \multicolumn{2}{|c|}{$\mathrm{n}=$} & \multicolumn{2}{|c|}{$\mathrm{n}=1$} & & \\
\hline & 5 & $\%$ & 8 & $\%$ & & \\
\hline Normal (less than & & & & 10 & & \\
\hline $5.7 \%)$ & 0 & 0 & 1 & 0 & & 1 \\
\hline Prediabetes (5.7 - & & & & 10 & & \\
\hline $6.4 \%)$ & 0 & 0 & 10 & 0 & & 10 \\
\hline Diabetes $(6.5 \%$ or & & 41. & & 58. & 0.0 & \\
\hline more) & 5 & 7 & 7 & 3 & 53 & 12 \\
\hline
\end{tabular}

\section{DISCUSSION}

The prevalence found in this study is lower than that reported by the ENSE in the 80's when the prevalence of seropositivity for T. cruzi was 3.2\% in Hidalgo (Monteón et al., 2005). Although the ENSE carried out their evaluation in rural areas with a different methodology than that applied in this study, it provides a panorama of the prevalence of seropositivity for $T$. cruzi in the state in the last 30 years.

In comparison to other transfusion centers, the prevalence of anti-T. cruzi antibodies registered in this work is lower than that reported in donors from transfusion centers in the State of Puebla (Schäffler, Müller-Ladner, Schölmerich, \& Büchler, 2006) (1.24\%). However, the prevalence could be greater since our work did not include biological samples from all blood transfusion centers in the state, only individuals who came directly to the CETS. The inclusion of donor population from other transfusion centers could increase the recorded prevalence.

La evidencia clínica-epidemiológica que une la enfermedad de Chagas, la obesidad y la diabetes es controversial y objeto de estudio (dos Santos et al., 1999); (Geraix, Ardisson, Marcondes-Machado, \& Pereira, 2007), (Hidron et al., 2010). La presencia de $T$. cruzi en los adipositos y tejido adiposo ha mostrado alteraciones en diferentes vías metabólicas durante las primeras etapas de la infección que persisten hasta la fase crónica. La alta afinidad de $T$. cruzi por las lipoproteínas facilita la invasión de las células y contribuye a la permanecia del parasito en el tejido adiposo (Nagajyothi et al., 2012).

Trabajos como los realizados por Navarro y colaboradores en 2013, reportaron que el $90 \%$ de los pacientes con alguna forma indeterminada de EC presentaban obesidad o sobrepeso en una muestra de 74 individuos. En 2007, Geraix y colaboradores, reportaron valores del $12 \%$ de hiperglicemia y $74 \%$ de dislipidemias en población afectada por la EC. Si bien los 
resultados de nuestro trabajo no evidencian una asociación entre los valores de hiperglicemia y la enfermedad de Chagas, destaca que el $100 \%$ de los casos positivos a $T$. cruzi presentaban valores de HbA1c mayor o igual a $6.5 \%$ y $60 \%$ presentaba sobrepeso u obesidad. Recientemente se demostró que la EC no se asocia con DM por lo que los autores concluyen que parasitismo del tejido adiposo por parte de $T$. cruzi no se traduce en anomalías de glucosa clínicamente relevantes (Resende et al., 2021) por lo que valores de hiperglucemia reportados en estudios previos incluyendo nuestro trabajo, se atribuirían a la alta prevalencia en enfermedades como diabetes con $12.8 \%$, sobrepeso y obesidad con $17.1 \%$ y $12.3 \%$ respectivamente (Instituto Nacional de Salud Pública, 2018), aunado a una baja prevalencia EC $0.1 \%$ de en el estado de Hidalgo. Entre las limitaciones del trabajo hacemos mencion a que no se realizó seguimiento a largo plazo de los reactivos a T.cruzi con hiperglucemia que permitiera confirmar o descartar la progresión hacia DM.

\section{CONCLUSIONS}

This work found a seroprevalence of $T$. cruzi of $0.1 \%$ in a population that uses the SBTC. Of those positive, $100 \%$ stated that they lived in one of the municipalities of the State of Hidalgo. And $100 \%$ of those positive stated that they did not have hyperglycemia.

Although the results do not show an association between the hyperglycemia values and Chagas disease, it is worth noting that $100 \%$ of the cases positive for T. cruzi had an HbA1c value greater than or equal to $6.5 \%$. Considering that hyperglycemia is a risk factor for the development of chronic diseases such as diabetes mellitus, long-term follow-up of the identified participants represents an area of opportunity for the clinical and epidemiological study of $T$. cruzi seropositive participants.

\section{ACKNOWLEDGMENTS}

Expresamos nuestro agradecimiento al personal del Centro Estatal de Transfusión Sanguinea por su apoyo recibido y revisor por sus comentarios al manuscrito.

\section{REFERENCES}

American Diabetes Association. (2021). Understanding A1C A1C does it all. Recuperado el 11 de octubre de 2021, de https://www.diabetes.org/a1c.

Barraza Lloréns, M., Guajardo-Barrón, V Hernández Viveros, C., Picó Guzmán, F., Crable, E., García González, R., Mora Alba, F., ... Urtiz Madrigal, A. (2015). Carga económica de la diabetes mellitus en México, 2013. Funsalud. Recuperado de http://www.funsalud.org.mx.

Bechah, Y., Paddock, C. D., Capo, C., Mege, J. L., \& Raoult, D. (2010). Adipose tissue serves as a reservoir for recrudescent Rickettsia prowazekii infection in a mouse model. PLoS ONE, 5(1), 1-7. https://doi.org/10.1371/journal.pone.0008547.

Carabarin-Lima, A., González-Vázquez, M. C., Rodríguez-Morales, O., Baylón-Pacheco, L., Rosales-Encina, J. L., Reyes-López, P. A., \& Arce-Fonseca, M. (2013). Chagas disease (American trypanosomiasis) in Mexico: An update. Acta Tropica, 127(2), 126-135. https://doi.org/10.1016/j.actatropica.2013.04.007.
Chagas, C. (2009). Nouvelle espèce de trypanosomiase humaine. Bulletin de la Societe de Pathologie Exotique, 102(5), 352-355.

Combs, T. P., Nagajyothi, Mukherjee, S., De Almeida, C. J. G., Jelicks, L. A., Schubert, W., ... Scherer, P. E. (2005). The adipocyte as an important target cell for Trypanosoma cruzi infection. Journal of Biological Chemistry, 280(25), 24085-24094. https://doi.org/10.1074/jbc.M412802200.

Desruisseaux, M. S., Nagajyothi, Trujillo, M. E., Tanowitz, H. B., \& Scherer, P. E. (2007). Adipocyte, adipose tissue, and infectious disease. Infection and Immunity, 75(3), 1066-1078. https://doi.org/10.1128/IAI.01455-06.

Dos Santos, V. M., da Cunha, S. F., Teixeira, V. P., Monteiro, J. P., dos Santos, J. A., dos Santos, T. A., ... da Cunha, D. F. (1999). Freqüência de diabetes mellitus e hiperglicemia em mulheres chagásicas e nao-chagásicas. Revista da Sociedade Brasileira de Medicina Tropical, 32(5), 489-496. https://doi.org/10.1590/S003786821999000500004 .

Dumonteil, E. (1999). Update on Chagas' disease in Mexico. Salud Publica de Mexico, 41(4), 322-327. https://doi.org/10.1590/S003636341999000400010.

Geraix, J., Ardisson, L. P., Marcondes-Machado, J., \& Pereira, P. C. M. (2007). Clinical and nutritional profile of individuals with chagas disease. Brazilian Journal of Infectious Diseases, 11(4), 411-414. https://doi.org/10.1590/S1413-86702007000400008.

Hidron, A. I., Gilman, R. H., Justiniano, J., Blackstock, A. J., LaFuente, C., Selum, W., ... Bern, C. (2010). Chagas cardiomyopathy in the context of the chronic disease transition. PLoS Neglected Tropical Diseases, 4(5). https://doi.org/10.1371/journal.pntd.0000688.

Instituto Nacional de Salud Pública. (2018). ENSANUT. Encuesta Nacional de Salud y Nutrición. Hidalgo. Recuperado el 5 de noviembre de 2021, de

https://ensanut.insp.mx/encuestas/ensanut2018/doctos/informes/Re sultado_Entidad_Hidalgo.pdf.

Lozano, A. R., Gómez-Dantés, H., Pelcastre, V. B. E., Ruelas, G. M. G., Montañez, J. C., Campuzano, J. C., ... González, V. J. J. (2014). Carga de la enfermedad en México 1990-2010. Nuevos resultados y desafíos (Primera). México: Instituto Nacional de Salud Pública / Secretaría de Salud..

Monteón, V. M., Reyes-López, P. A., Sosa-Palacio, A., León-Tello, G., Martínez-Murguía, J., \& Sosa-Jurado, F. (2005). Distribución heterogénea de la prevalencia de anticuerpos contra Trypanosoma cruzi en donadores de sangre en Puebla, México. Salud Publica de Mexico, 47(2), 116-125. https://doi.org/10.1590/S003636342005000200005 .

Nagajyothi, F., Desruisseaux, M. S., Jelicks, L. a, Machado, F. S., Chua, S., Scherer, P. E., \& Tanowitz, H. B. (2009). Perspectives on adipose tissue, chagas disease and implications for the metabolic syndrome. Interdisciplinary perspectives on infectious diseases, 2009, 824324. https://doi.org/10.1155/2009/824324

Nagajyothi, F., Machado, F. S., Burleigh, B. A., Jelicks, L. A., Scherer, P. E., Mukherjee, S., ... Tanowitz, H. B. (2012). Mechanisms of Trypanosoma cruzi persistence in Chagas disease. Cellular Microbiology, 14(5), 634-643. https://doi.org/10.1111/j.14625822.2012.01764.x

Navarro, E. C., Miziara De Abreu, M., Tavares, F. C., Corrente, J. E., Maria De Arruda, C., Câmara, P., \& Pereira, M. (2013). Indeterminate Form of Chagas' Disease and Metabolic Syndrome: A Dangerous Combination. American Journal of M edicine and $M$ edical Sciences, 3(4), 68-73. https://doi.org/10.5923/j.ajmms.20130304.03.

Neyrolles, O., Hernández-Pando, R., Pietri-Rouxel, F., Fornès, P., Tailleux, L., Payán, J. A. B., ... Gicquel, B. (2006). Is adipose tissue a place for Mycobacterium tuberculosis persistence? PLoS ONE, 1(1). https://doi.org/10.1371/journal.pone.0000043.

Ramsey, J., Ordoñez, R., Tello-López, A., Pohls, J. L., Sanchez, V., \& 
Peterson, a T. (2003). Actualidades sobre la epidemiología de la enfermedad de Chagas en México. Researchgate, (May 2017), 85103.

Resende, B. A. M., Beleigoli, A. M. R., Ribeiro, A. L. P., Duncan, B., Schmidt, M. I., Mill, J. G., ... Diniz, M. D. F. H. S. (2021). Chagas disease is not associated with diabetes, metabolic syndrome, insulin resistance and beta cell dysfunction at baseline of Brazilian Longitudinal Study of Adult Health (ELSA-Brasil). Parasitology International, 85(August). https://doi.org/10.1016/j.parint.2021.102440.

Saumell, C. R., \& Soriano-arandes, A. (2015). Documento de consenso sobre el abordaje de la enfermedad de Chagas en atención primaria de salud de áreas no endémicas. Atención Primaria, 47(5), 308317.

Schäffler, A., Müller-Ladner, U., Schölmerich, J., \& Büchler, C. (2006). Role of adipose tissue as an inflammatory organ in human diseases. Endocrine Reviews, 27(5), 449-467. https://doi.org/10.1210/er.2005-0022.

Secretaria de Salud. (2012). NORMA Oficial Mexicana NOM-253-SSA12012, Para la disposición de sangre humana y sus componentes con fines terapéuticos, 2012.

Velasco- Castrejon, O., Valdespino, J. L., Tapia-Conyer, R., Salvatierra, B., Guzmán- Bracho, C., Magos, C., ... Sepulveda, J. (1992). Seroepidemiología de la enfermedad de Chagas en México. Salud Pública de México, 34(2), 186-196. https://doi.org/10.1590/S0102$311 \mathrm{X} 200200060002400028$.

World Health Organization. (2021). Chagas disease (also known as American trypanosomiasis). Recuperado el 11 de octubre de 2021, de https://www.who.int/news-room/fact-sheets/detail/chagasdisease-(american-trypanosomiasis). 